\title{
Training On Biogas Production From Manure And Concrete Brick Production To Improve The Economy Of Citizen In Danau Sadar Village, Central Kalimantan
}

\section{Pelatihan Pembuatan Biogas Dari Kotoran Ternak Dan Pembuatan Batako Untuk Meningkatkan Perekonomian Masyarakat Desa Danau Sadar Kalimantan Tengah}

\author{
Lilis Rosmainar $^{1)}$, Karelius ${ }^{1)}$, Rasidah ${ }^{1)}$, Akhmad Damsyik ${ }^{1)}$, I Made Sadiana ${ }^{2)}$, Revianti Coenraad ${ }^{3)}$, Tia Monika ${ }^{1 /}$ \\ 1)Program Studi Kimia FMIPA, Universitas Palangka Raya \\ 2) Program Studi Pendidikan Kimia FKIP, Universitas Palangka Raya \\ ${ }^{3)}$ Program Studi Pendidikan Teknik Bangunan FKIP, Universitas Palangka Raya \\ e-mail: karelius@chem.upr.ac.id
}

\begin{abstract}
Danau Sadar Village is a village located in the sub-district of Dusun Selatan, $8 \mathrm{~km}$ from Buntok, the capital of South Barito Regency. This village has several potentials such as rubber plantation, livestock sector, tourism, and fisheries sector. Even though this potential is quite remarkable, the citizen welfare is still in low catagories due to the lack of skill in managing it. This condition happened because not all workers are engaged in the production process. Related to the condition of the community in Danau Sadar Village, an idea emerged to empower the community, by providing training to improve their skills. The objectives of community service in Danau Sadar Village are as follows: (1) assisting the people of Danau Sadar Village in developing economic independence; (2) improving entrepreneurial skills through the training provided. The community service program has been successful by carrying out two types of training activities to improve citizen welfare: training on biogas reactors from manure and brick making to obtain optimal products in terms of production costs and quality. The citizen in Danau Sadar Village welcomes this community service program. They hope that Palangka Raya University will carry out the community service program regularly in their village.

Keywords: biogas, fuel, concrete brick, community service, Danau Sadar
\end{abstract}

\begin{abstract}
ABSTRAK
Desa Danau Sadar adalah sebuah desa yang terletak di wilayah Kecamatan Dusun Selatan, berjarak $8 \mathrm{~km}$ dari Buntok, ibu kota Kabupaten Barito Selatan. Desa ini memiliki beberapa potensi yaitu perkebunan karet, sektor peternakan, sektor pariwisata dan perikanan. Kendatipun potensi tersebut cukup besar, namun karena kurangnya kemampuan/keterampilan masyarakat di dalam mengelolanya maka tingkat kesejahteraan masyarakat juga masih rendah. Hal ini disebabkan karena belum semua potensi tenaga kerja yang ada bergerak melakukan proses produksi. Terkait dengan kondisi masyarakat di Desa Danau Sadar, muncullah suatu gagasan untuk memberdayakan masyarakat, dengan memberikan pelatihan untuk meningkatkan keterampilan mereka. Pelatihan ini diharapkan dapat meningkatkan kesejahteraan masyarakat di desa tersebut. Secara umum, tujuan PKM Desa Danau Sadar adalah sebagai berikut: (1) Membantu masyarakat Desa Danau Sadar untuk mengembangkan kemandirian secara ekonomi; (2) Meningkatkan keterampilan berwirausaha melalui pelatihan yang diberikan. Telah dilakukan PKM Pemberdayaan Masyarakat Desa Danau Sadar dalam bidang perkebunan karet, peternakan dan industri rumah tangga dalam rangka usaha meningkatkan Kesejahteraan Masyarakat. Secara umum, kegiatan ini berjalan dengan sukses, dengan melakukan 2 jenis kegiatan pelatihan, yaitu di bidang peternakan dengan melaksanakan pelatihan pembuatan reaktor biogas dari kotoran ternak babi dan ayam sebagai percontohan pembuatan biogas dari kotoran ternak serta di bidang industri rumah tangga dengan melaksanakan pelatihan pembuatan batako untuk mendapatkan produk yang optimal dalam biaya produksi dan kualitas. Masyarakat di Desa Danau Sadar menyambut dengan baik kegiatan pengabdian kepada masyarakat yang dilaksanakan oleh Universitas Palangka Raya, selanjutnya mereka berharap dilakukan kegiatan PKM secara rutin di desa tersebut.

Kata kunci: biogas, bahan bakar, batako, PkM, Danau Sadar
\end{abstract}

\section{PENDAHULUAN}

Desa Danau Sadar adalah sebuah desa yang terletak di wilayah Kecamatan Dusun Selatan, berjarak 8 km dari Buntok, ibu kota Kabupaten Barito Selatan. Desa Danau Sadar dapat dicapai dengan mudah karena akses jalan darat sudah cukup baik. Potensi yang paling menonjol dari Desa Danau Sadar adalah perkebunan karet. Sebagian besar penduduknya bermata pencaharian sebagai petani karet yang masih dikelola secara sederhana.

Di samping sektor perkebunan, sektor peternakan juga menjadi salah satu sumber pendapatan warga, 
mayoritas keluarga memiliki ternak 2-3 ekor babi dan beberapa ekor ayam yang dipelihara secara tradisional. Warga yang memelihara babi dan ayam memanfaatkan sampah-sampah rumah tangga untuk menjadi makanan ternak-ternak tersebut.

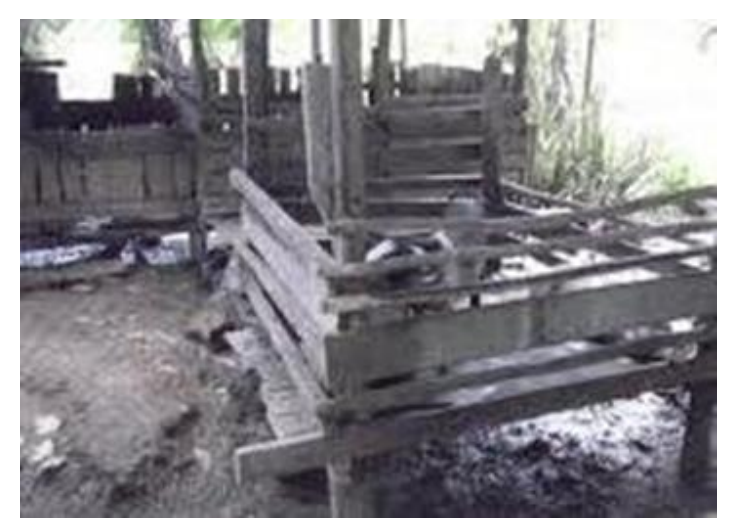

Gambar 1. Pemeliharaan ternak babi secara tradisional

Rendahnya tingkat kesejahteraan masyarakat dapat dilihat dari masih tingginya tingkat kemiskinan, rendahnya tingkat kesehatan dan rendahnya tingkat pendidikan.

Terkait dengan kondisi masyarakat di Desa Danau Sadar, muncullah suatu gagasan untuk memberdayakan masyarakat, dengan memberikan pelatihan untuk meningkatkan keterampilan mereka. Sejumlah penelitian menunjukkan bahwa limbah ternak dapat dimanfaatkan sebagai sumber biogas (Yahya et al., 2018; Putri et al., 2019; dan Suriman et al., 2021). Lebih lanjut lagi, hasil penelitian (Elly et al., 2020) menunjukkan bahwa teknologi biogas bermanfaat bagi petani dalam minimalisasi biaya pembelian gas LPG dan menghasilkan pupuk cair. Dengan adanya pelatihan diharapkan dapat meningkatkan kesejahteraan masyarakat di desa tersebut. Munculnya gagasan ini adalah didasari oleh adanya kesadaran bahwa Perguruan Tinggi (Universitas Palangka Raya) sudah sepantasnya ikut menyumbangkan karya nyata untuk meningkatkan kesejahteraan masyarakat di luar kampus termasuk masyarakat di desa Danau Sadar. Secara umum, tujuan PKM Desa Danau Sadar adalah sebagai berikut: (1) Membantu masyarakat Desa Danau Sadar untuk mengembangkan kemandirian secara ekonomi; (2) Meningkatkan keterampilan berwirausaha melalui pelatihan yang diberikan.

Program PKM di Desa Danau Sadar diinspirasi dari kondisi dan kebutuhan riil di desa tersebut. Beberapa kondisi riil yang dimaksud antara lain:
1 Bidang Peternakan: Kotoran ternak babi dan ayam dibiarkan menumpuk tanpa penanganan berarti, bahkan ada yang dibuang langsung ke kali/danau, sehingga menyebabkan pencemaran. Pencemaran air tersebut dapat mengganggu kesehatan penduduk di sekitar kali/danau yang tercemar, padahal menurut data terdapat lebih dari 90 RT yang tinggal disekitar bantaran kali/danau tersebut (BPS, 2012). Sementara itu, sebagian besar warga masih menggunakan kayu bakar untuk keperluan memasak hari- hari, karena sulitnya mendapatkan minyak tanah dan gas;

Bidang industri paving dan batako: Tidak banyak penduduk lokal yang bergerak di bidang industri rumah tangga, terutama bahan bangunan. Hal ini disebabkan karena penguasaan pengetahuan dan keterampilan yang belum memadai. Batako merupakan bahan bangunan yang umum mereka gunakan untuk pekerjaan konstruksi karena bahan bakunya cukup banyak tersedia. Harga jual batako masih cukup mahal, karena biaya produksi cukup tinggi, salah satu penyebabnya adalah karena komposisi campuran dan metode pembuatan yang tidak tepat, sehingga berdampak pada tingginya nilai jual. Selain itu, kualitas batako yang dibuat tidak stabil, terkadang kuat, tapi sering kali batako yang dihasilkan rapuh/mudah hancur. Hal ini disebabkan kurangnya pengetahuan tentang pembuatan beton (dalam hal ini batako dan paving) dan metode perawatan beton. 

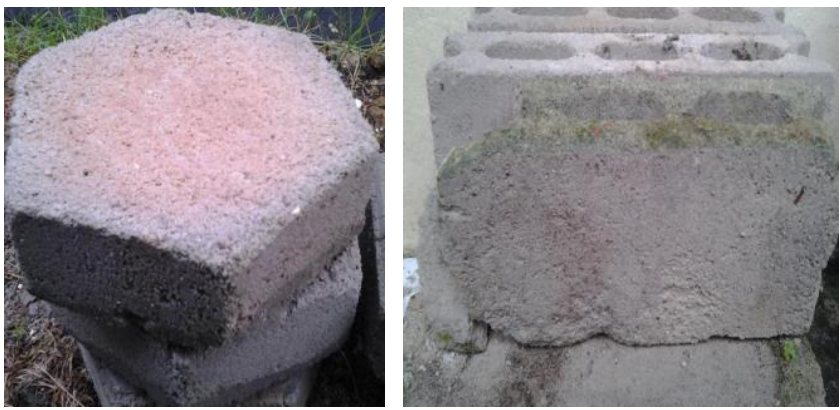

Gambar 2. Contoh hasil produksi paving dan batako

Salah satu permasalahan yang dihadapi oleh masyarakat Desa Danau Sadar adalah kesulitan dalam mendapatkan minyak tanah dan LPG sebagai bahan bakar. Secara ekonomi masyarakat kurang mampu membeli tabung gas tersebut, terlebih lagi mengingat sebagian besar masyarakat Desa Danau Sadar merupakan masyarakat dengan tingkat ekonomi menengah ke bawah. Kami berinisiatif untuk melakukan optimalisasi potensi sumber energi alternatif di desa ini dengan menggunakan kotoran ternak babi dan ayam untuk proses instalasi biogas. Dengan adanya program optimalisasi potensi biogas ini, akan dapat meningkatkan kesejahteraan warga. Selanjutnya, dapat menjadi suatu sumber pemasukan baru bagi warga Desa Danau Sadar, salah satunya dengan mengkomersialisasikan ilmu dan pengalaman warga Desa Danau Sadar tentang pembangunan instalasi biogas kepada pihak luar manapun yang berminat terhadap teknologi biogas ini.

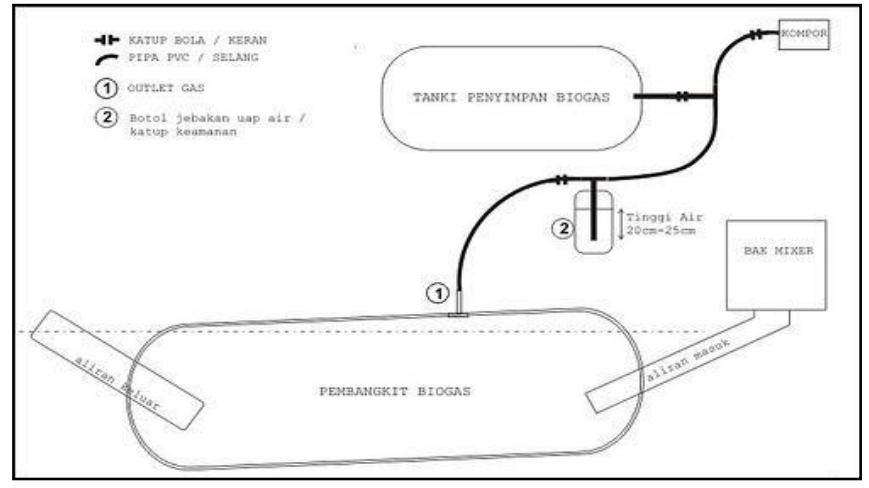

Gambar 3. Instalasi Biogas

2 Pelatihan pembuatan paving dan batako yang bernilai ekonomis bagi warga yang sudah memiliki usaha tersebut dan warga yang mempunyai minat untuk terjun ke bidang usaha pembuatan paving dan batako. Tujuan pelatihan pembuatan batako dan paving bagi warga Desa Danau Sadar adalah sebagai berikut:

- Memiliki minat untuk berwirausaha dalam bidang produksi bahan bangunan berbahan pasir khususnya batako dan paving block.

- Memiliki kecakapan hidup dalam aspek vocational skill dalam bidang produksi bahan bangunan berbahan pasir dengan baik.

- Memperoleh bekal keterampilan pengelolaan produksi dan penjualan bahan bangunan berbahan pasir.

- Dapat mengembangkan usaha produksi bahan bangunan berbahan pasir dengan mutu produk yang baik.

- Mengetahui mutu produk yang dihasilkan.
- Memperoleh pendapatan yang layak dari usaha yang dirintisnya.

Kegiatan pelatihan ini berupa: (1) pemberian ceramahan tentang bahan-bahan pembentuk batako, (2) pelatihan ketrampilan pembuatan batako yang berkualitas baik, (3) ceramah kewirausahaan dalam kaitannya bisnis bahan bangunan khususnya batako, (4) praktik pembuatan batako dengan perbandingan tertentu untuk mencapai kualitas yang baik, (5) uji laboratorium kualitas batako yang dihasilkan.

\section{METODE PELAKSANAAN PENGABDIAN}

Ada beberapa metode/model yang diterapkan dalam pelaksanaan program, yaitu:

1. Model Partisipatory Rural Apprasial (PRA), menekankan pada keterlibatan masyarakat. Model ini digunakan untuk mengidentifikasi masalah yang dialami mitra atau kelompok masyarakat. Mitra harus diikutsertakan dalam kegiatan merumuskan masalah, mengatasi 
masalah, penentuan proses dan kriteria masalah. Penggunaan model pendekatan ini diharapkan akan: (1) dikenalnya masalah secara tepat/efektif sesuai dengan persepsi, kehendak, dan ukuran/kemampuan serta kebutuhan mereka, (2) tumbuhnya kekuatan (enpowering) masyarakat atau kelompok sasaran dalam pengalaman merancang, melaksanakan, mengelola dan mempertanggungjawabkan sebagai upaya peningkatan/pertumbuhan diri dan ekonominya, dan (3) efektifitas dan efisiensi penggunaan sumber daya mitra atau kelompok masyarakat. Observasi dilakukan terus- menerus sejalan dengan setiap langkah yang akan ditempuh.

2. Model Enthrepreneurship Capasity Building (ECB), memberikan wawasan, sikap, dan keterampilan bewirausaha; Keterampilan berwirausaha merupakan bekal hidup yang sangat berharga di masa yang akan datang karena manusia yang terampil selalu dapat mencari solusi untuk memenuhi kebutuhan riil dalam kehidupannya. Dengan demikian seseorang yang mempunyai keterampilan hidup yang tinggi akan berpeluang besar untuk mendapat keuntungan yang tidak sedikit di masa-masa yang akan datang.

3. Model Technology Transfer (TT), menguasai prinsip-prinsip penerapan teknologi terutama yang berkaitan dengan program yang akan dilaksanakan;

Dalam kegiatan yang berbentuk pendidikan dan pelatihan, masyarakat diposisikan sebagai peserta, sedangkan tutor dan nara sumber diperankan oleh tim pelaksana PKM. Dalam kegiatan yang berbentuk pembinaan dan pendampingan terhadap usaha/industri, masyarakat pemilik dan pengelola usaha/industri diposisikan sebagai pihak yang dibina dan didampingi.

Adapun tahapan pelaksanaan PKM Desa Danau Sadar direncanakan sebagai berikut:

\section{Tahap Persiapan}

- Koordinasi awal dengan Kepala Desa Danau Sadar untuk mensosialisasikan kegiatan PKM, sekaligus meminta kerjasama dengan perangkat desa yang bersangkutan.

- Survey waktu dan tempat pelaksanaan, dipilih ketika waktu senggang masyarakat.

- Pendataan warga yang akan mengikuti 3 jenis pelatihan yang diberikan, yaitu pelatihan karet, pelatihan pembuatan biogas dan pelatihan paving/batako, dan mengidentifikasi warga yang sanggup mengikuti program ini. Dimana pelatihan karet ditunjukan untuk petani karet, pelatihan biogas ditujukan bagi warga yang memelihara ternak ayam dan babi, serta pelatihan peving/batako ditujukan bagi warga yang sudah mempunyai industri tersebut ataupun yang berminat untuk menggeluti usaha pembuatan paving dan batako.

- Persiapan alat dan bahan pelatihan yang tepat, sehingga pelatihan dapat dilakukan secara efektif dan efisien.

- Pendekatan persuasif kepada masyarakat dengan maksud agar masyarakat mengerti tujuan dari program ini.

- Penyusunan modul pelatihan yang berisi petunjuk teknis dan materi pelatihan yang akan diberikan.

\section{Tahap Pelaksanaan}

Dua jenis pelatihan akan dilaksanakan secara terpisah, dan diikuti oleh warga yang sudah didata sebelumnya, sesuai dengan kebutuhan masing-masing. Adapun tahapan pelaksanaan adalah sebagai berikut:

- Penyuluhan teknis, berisi ceramah oleh pakar bidang masing-masing sesuai dengan kegiatan pelatihan yang dilakukan. Peserta pelatihan akan diberikan modul pelatihan yang akan membantu mereka mengerti materi yang diberikan.

- Penyuluhan tinjauan ekonomis, berisi ceramah tentang aspek ekonomis pelatihan yang diberikan, bertujuan untuk menarik minat warga untuk menerapkan teknologi yang ditransferkan.

- Persiapan alat dan bahan untuk kegiatan praktik lapangan.

- Praktik lapangan berisi kegiatan praktik, dalam hal ini pembuatan reaktor pirolisis sederhana, pembuatan instalasi biogas dan pembuatan paving dan batako, yang akan dimentori oleh pakarnya masing-masing.

\section{Tahap Pelaporan}

Tahapan ini merupakan tahapan terakhir yaitu menyusun laporan kegiatan pelaksanaan PKM di Desa Danau Sadar. Selanjutnya mengadakan seminar hasil pelaksanaan PKM sebagai salah satu bentuk publikasi yang dilakukan tim pelaksana.

\section{HASIL DAN PEMBAHASAN}

Kegiatan pengabdian masyarakat di desa Danau Sadar memasuki tahap persiapan pada minggu ke-3 di bulan April 2020. Tim pengabdi melakukan koordinasi dengan kepala desa setempat mengenai kegiatan PKM, dan mereka menyambut baik rencana pelaksanaan kegiatan PKM tersebut. Berdasarkan hasil koordinasi dengan kepala desa dan perwakilan warga, kegiatan 
pelatihan akan dilaksanakan pada minggu ke-2 sampai minggu ke-4 bulan Juni 2020. Selain berkoordinasi, tim juga melakukan survey tempat pelaksanaan kegiatan PKM di Balai Desa Danau Sadar serta melakukan pendataan warga yang akan mengikuti pelatihan. Kegiatan untuk menyediakan peralatan dan bahan pelatihan dilakukan di Palangka Raya dan di Desa Danau Sadar. Modul pelatihan kegiatan juga dibuat untuk dibagikan kepada peserta pelatihan, sebagai bahan pegangan pada saat kegiatan pelatihan.

Warga sangat antusias mengikuti pelatihan, ini terbukti dengan banyaknya pertanyaan yang diajukan oleh mereka selama 1 jam sesi tanya jawab. Bahkan beberapa warga mengusulkan agar bahan dan peralatan yang diberikan kepada desa Danau Sadar dapat segera dimanfaatkan untuk membuka industri rumah tangga, yang nantinya dapat dirasakan hasilnya oleh seluruh warga, walaupun pengelolaannya dilakukan oleh pihak aparat desa.

Secara umum, kegiatan PKM ini berlangsung dengan sukses, dan warga desa Danau Sadar berharap dapat dilaksanakan lagi pada tahun-tahun mendatang. Berikut ini adalah hasil dan pembahasan kegiatan PKM yang dilakukan di Desa Danau Sadar:

\section{Pelatihan Pembuatan Reaktor Biogas}

Sektor peternakan juga menjadi salah satu sumber pendapatan warga Desa Danau Sadar, mayoritas keluarga memiliki ternak 2-3 ekor babi dan beberapa ekor ayam yang dipelihara secara tradisional. Warga yang memelihara babi dan ayam memanfaatkan sampah-sampah rumah tangga untuk menjadi makanan ternak-ternak tersebut. Kotoran ternak babi dan ayam dibiarkan menumpuk tanpa penanganan berarti, bahkan ada yang dibuang langsung ke kali/danau, sehingga menyebabkan pencemaran. Pencemaran air tersebut dapat mengganggu kesehatan penduduk di sekitar kali/danau yang tercemar, padahal menurut data terdapat lebih dari 90 RT yang tinggal disekitar bantaran kali/danau tersebut (BPS, 2012). Sementara itu, sebagian besar warga masih menggunakan kayu bakar untuk keperluan memasak sehari-hari, karena sulitnya mendapatkan minyak tanah dan gas LPG serta harga minyak tanah dan gas LPG yang terus melambung naik. Hal ini sangat menyulitkan warga setempat karena harus mencari kayu bakar di sekitar hutan dekat tempat tinggal mereka dengan jarak yang cukup jauh, apalagi bila musim penghujan tiba persediaan kayu bakar menjadi sangat terbatas.

Salah satu alternatif pemanfaatan limbah dari hewan ternak sebagai sumber energi baru yang dapat diperbarukan adalah Biogas. Biogas adalah bahan bakar yang berupa gas yang dihasilkan dari proses fermentasi anaerob oleh mikroorganisme dari bahan organik, seperti limbah pertanian, kotoran ternak, kotoran manusia atau campurannya di dalam suatu alat yang disebut digester. Proses pembentukan Biogas terdiri dari beberapa tahapan antara lain:

1. Hidrolisis: terjadi penguraian bahan mudah larut dan bahan komplek menjadi sederhana. Bakteri yang berperan Clostridium acteinum, Bacteriodes ruminicola, Bifidobacterium $s p$, Eschericia $s p$, Enterobacter $s p$, dan Desulfobio $s p$.

2. Pengasaman: bahan yang terbentuk pada tahap 1 akan menjadi bahan makanan bagi bakteri metanogenik. Bakteri mengoksidasi asam berantai karbon panjang, seperti asetat dan alkohol yang dilakukan oleh Lactobacillus sp, Streptococcus sp.

3. Metanogenik pembentukan gas metan. Bakteri methanogenik menggunakan $\mathrm{H} 2, \mathrm{CO} 2$, dan asetat untuk pertumbuhannya, serta memproduksi $\mathrm{CH} 4$ dan CO2. Urea yang berasal dari protein dihidrolisa oleh bakteri menjadi gas metan ( $\mathrm{CH} 4)$ dan $\mathrm{NH} 4+$. Asam asetat serta asam propionat dari lemak difermentasi menjadi gas metan dan $\mathrm{CO} 2$ .CO2 yang dihasilkan direduksi menjadi $\mathrm{CH} 4$ dan H2O.Bakteri yang berperan pada tahap ini adalah Methanobacterium melianskii, Methanococcus sp, dan Methanosarcina sp70\% metan dihasilkan dari asam asetat, 15\% dari $\mathrm{H} 2$ dan CO2, 15\% lagi dari reduksi metanol.

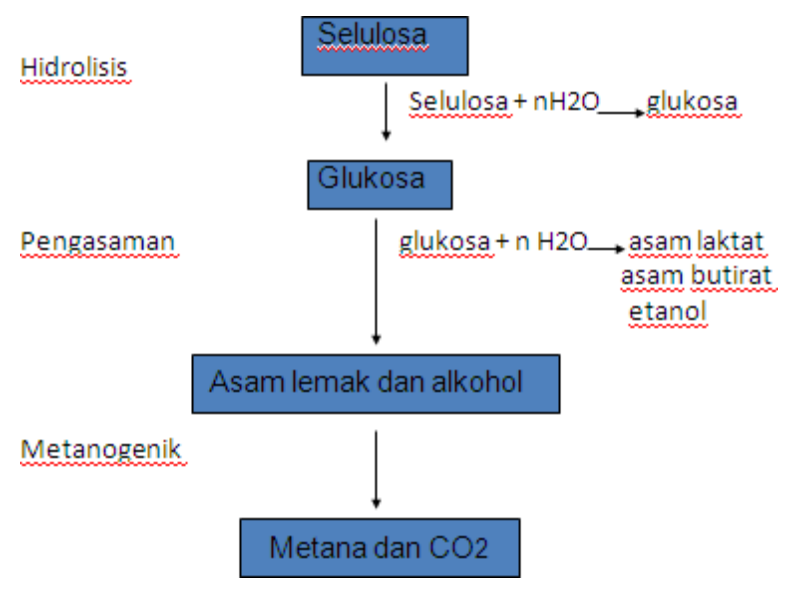

Gambar 4. Diagram alir proses pembentukan gas metan 
Prinsip utama proses pembentukan biogas adalah pengumpulan kotoran ternak atau kotoran manusia ke dalam tangki plastik/pralon yang kedap udara, yang disebut dengan tanki digester. Di dalamnya kotorankotoran tersebut akan dicerna dan difermentasi oleh bakteri-bakteri seperti disebutkan di atas. Gas yang dihasilkan akan tertampung dalam digester. Terjadinya penumpukan produksi gas akan menimbulkan tekanan sehingga dari tekanan tersebut dapat disalurkan melalui pipa yang dipergunakan untuk keperluan bahan bakar atau pembangkit listrik.

Gas tersebut sangat baik untuk pembakaran karena menghasilkan panas yang tinggi, tidak berbau, tidak berasap, dan api yang dihasilkan berwarna biru. Selain itu, pupuk kandang yang dihasilkan dari pembuangan bahan biogas ini akan menaikkan kandungan bahan organik sehingga menjadi pupuk kandang yang sangat baik dan siap pakai.

Jumlah dan jenis kotoran yang digunakan tentunya merupakan faktor yang penting karena mempengaruhi volume gas yang dihasilkan (Putri et al., 2014 dan Mayang et al., 2019). Pada kegiatan ini diperoleh hasil untuk kotoran Babi per $\mathrm{kg}$ dapat menghasilkan gas sekitar 0,040-0,059 m3 sedangkan untuk ayam per kg dapat menghasilkan 0,065-0,116 m3. Gas yang dihasilkan tentunya akan jauh lebih banyak lagi jika menggunakan kotoran sapi karena bahan dengan rasio $\mathrm{C} / \mathrm{N}$ yang tinggi akan menghasilkan biogas yang lebih banyak. Kotoran sapi memiliki rasio lebih tinggi dibandingkan dengan kotoran ayam (Yahya et al., 2018). Untuk membandingkan jumlah kotoran/tinja yang dihasilkan dari ternak, berikut ini gambaran dari perbandingan jumlah tersebut:

Tabel 1. Perbandingan jumlah kotoran yang dihasilkan ternak dan manusia

\begin{tabular}{|r|l|r|r|r|}
\hline \multirow{2}{*}{ No. } & Jenis Ternak & Jml. Tinja & \multicolumn{2}{|c|}{ Persentase Kandungan } \\
\cline { 5 - 6 } & & per hari/kg & \multicolumn{1}{c|}{ Air } & Bahan Kering \\
\hline 1 & Sapi & 28 & 80 & 20 \\
\hline 2 & Sapi perah & 28 & 80 & 20 \\
\hline 3 & Kerbau & 35 & 83 & 17 \\
\hline 4 & Kambing & 1,13 & 74 & 26 \\
\hline 5 & Domba & 1,13 & 74 & 26 \\
\hline 6 & Babi & 3,41 & 67 & 33 \\
\hline 7 & Avam/kampung/ras & 0,18 & 72 & 28 \\
8 & Itik & 0,34 & 62 & 38 \\
\hline 9 & Manusia & 0,15 & 77 & 23 \\
\hline
\end{tabular}

Sumber: buku saku peternakan dit. Bina program Dirjen Peternakan

Kesetaraan biogas dengan sumber energi lain 1 m3 biogas setara dengan: elpiji 0,46 kg, minyak tanah 0,62 liter, minyak solar 0,52 liter, bensin 0,80 liter, gas kota 1,50 m3, dan kayu bakar 3,50 kg. Sedangkan produksi biogas dari berbagai bahan organik dapat di lihat pada tabel berikut:

Tabel 2. Produksi biogas dari berbagai bahan organik

\begin{tabular}{|c|l|c|c|}
\hline No. & Bahan Organik & Jumlah (Kg) & Biogas (It) \\
\hline 1 & Kotoran Sapi & 1 & 40 \\
\hline 2 & Kotoran Kerbau & 1 & 30 \\
\hline 3 & Kotoran Babi & 1 & 60 \\
\hline 4 & Kotoran Ayam & 1 & 70 \\
\hline
\end{tabular}

Proses pembuatan biogas dengan menggunakan biodigester pada prinsipnya adalah menciptakan suatu sistem kedap udara dengan bagian-bagian pokok yang terdiri dari tangki pencerna (digester tank), lubang input bahan baku, lubang output lumpur sisa hasil pencernaan (slurry) dan lubang penyaluran biogas yang terbentuk. Dalam digester terkandung bakteri metana yang akan mengolah limbah organik menjadi biogas. 


\section{Bahan dan Peralatan}

Alat dan bahan yang perlu dipersiapkan untuk pembuatan reaktor biogas adalah semen 3 sak, pasir, plastik pollyethilene $20 \mathrm{~m}$, drum, pipa pralon lebar 3inchi, pipa pralon lebar $1 / 2$ inchi (18 meter), stop kran 4 buah, shockgrad 4buah, pipa L 7buah, pipa T 3buah, kompor

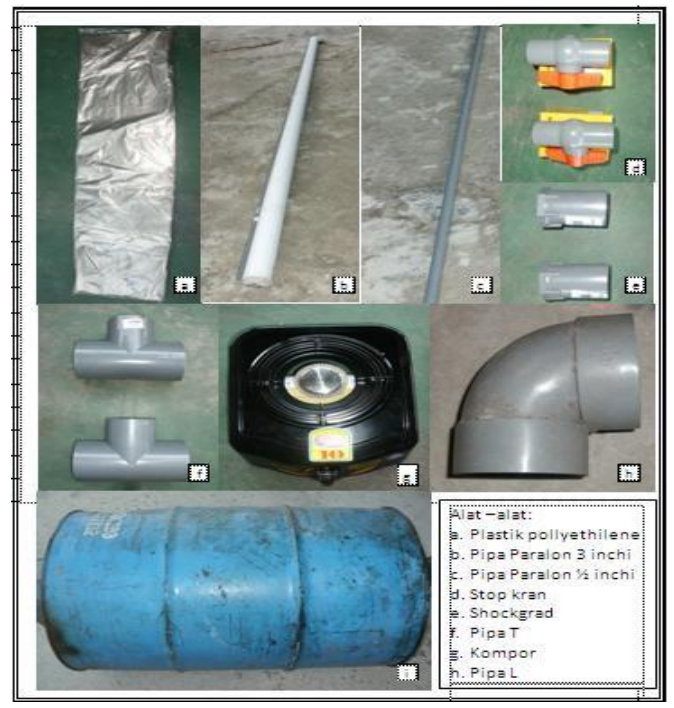

Gambar 5. Alat dan bahan untuk pembuatan reaktor biogas

Alat dan bahan tersebut kemudian dirancang dengan mengikuti skema rancangan pada gambar berikut:

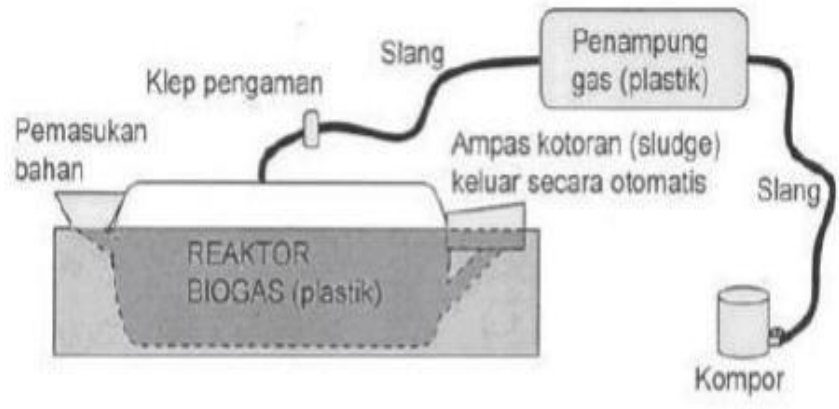

Gambar 6. Rancangan reaktor biogas

\section{Rangkaian Alat}

1. Pembuatan tabung pencerna

Tabung ini dibuat dari 1 buah drum besar (tabung 200 liter) yang berjumlah 1 drum, dilengkapi dengan pipa pemasukan isian dan pipa pengeluaran buangan. Pembuatan secara lengkap sebagai berikut :

a. Menguji kebocoran dengan cara memasukkan air dan diamati seluruh bagian drum. Kebocoran ditandai dengan keluarnya air dari bagian tersebut.

b. Jika ada kebocoran perlu diadakan penambalan dengan cara pengelasan.

c. Membuat lubang dengan diameter $8 \mathrm{~cm}$ tepat disisi tutup yang masih utuh kedua tersebut.

d. Membuat lubang diameter $1-1,5 \mathrm{~cm}$ di posisi atas drum.

e. Menyambung pipa pemasukan isian $(60 \mathrm{~cm})$ yang telah dilengkapi corong pada salah satu lubang dengan membentuk sudut $30^{\circ}$, kemudian mengelasnya. Untuk memperkuat perlu ditopang dengan plat baja

f. Menyambung pipa pengeluaran buangan $(60$ $\mathrm{cm})$ pada salah satu lubang dengan membentuk sudut $30^{\circ}$, kemudian dilas. Untuk memperkuat perlu ditopang dengan plat baja. 


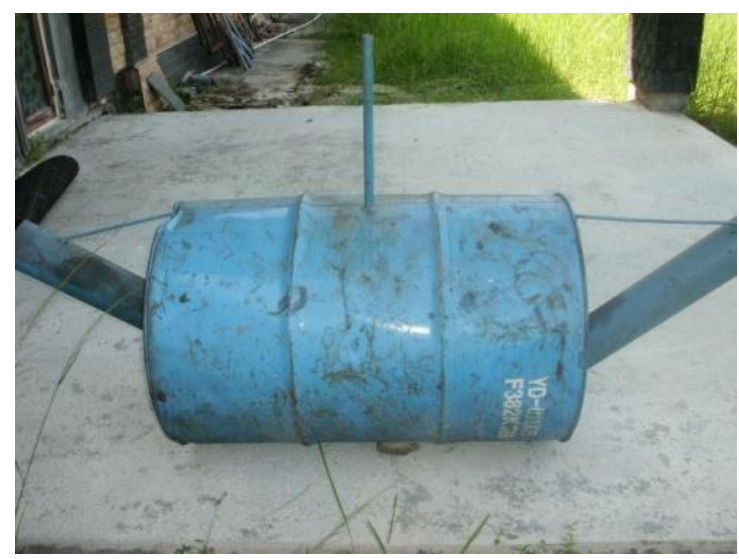

Gambar 7. Tabung pencerna (digester/reaktor)

\section{Pemasangan Reaktor/Digester Biogas}

1. Pembuatan lubang reaktor/digester, panjang $=4$ $\mathrm{m}$, lebar $=1,1 \mathrm{~m}$, dalam $=1,2 \mathrm{~m}$

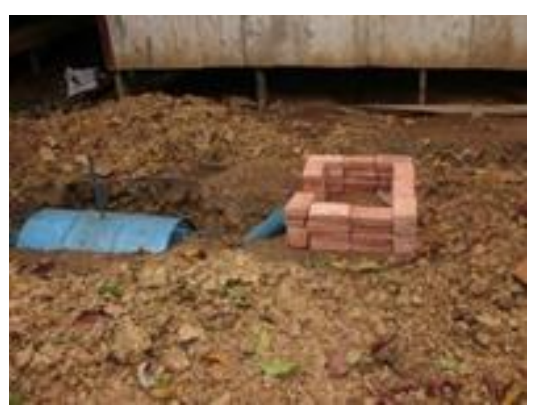

Gambar 8. Proses penggalian lubang digester/reactor
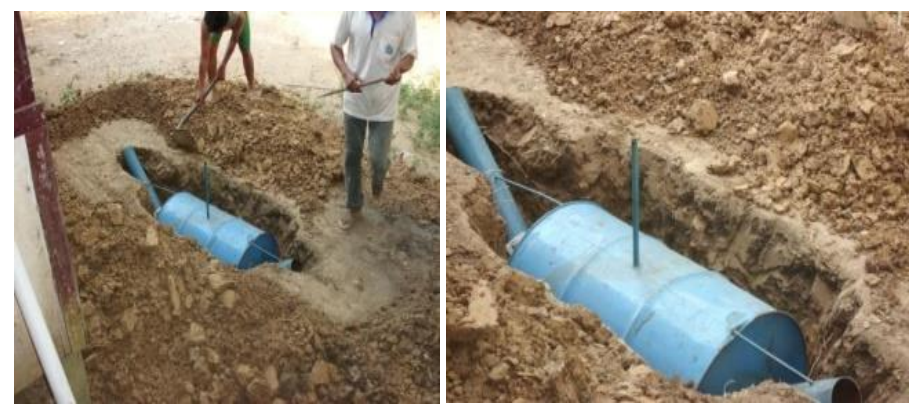

Gambar 9. Proses pemasukan digester ke dalam lubang galian

3. Pembuatan bak penampung kotoran yang terbuat dari batako dilakukan untuk lebih memudahkan pemasukan kotoran tempat pembuangan. Bak penampungan ini dibuat dengan posisi lebih miring menuju pipa masukan.

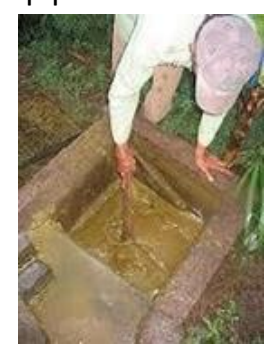

Gambar 10. Pembuatan Bak Penampungan Kotoran
2. Reaktor/digester biogas yang terbuat dari drum yang telah dimodifikasi sesuai dengan rancangan dimasukkan kedalam lubang galian hingga terkubur seluruhnya hal ini dimaksudkan untuk menjaga agar suhu dalam reaktor tetap stabil. Dengan posisi pipa masukan kotoran lebih tinggi dari pipa keluaran, kotoran hewan ternak babi atau ayam yang dimasukkan akan lebih mudah mengalir ke reaktor dan sisa hasil pengolahan bahan biogas berupa lumpur (sludge) dapat keluar secara otomatis dengan mudah.
4. Pembuatan tabung plastik penampung gas : (diameter $1,2 \mathrm{~m}$ ) panjang $=3 \mathrm{~m}$, lebar $=1,2 \mathrm{~m}$. selanjutnya dilakukan pemasangan instalasi pipa yang dilengkapi dengan klep pengaman dari reaktor digester yang terhubung dengan tabung plastik penampung gas.
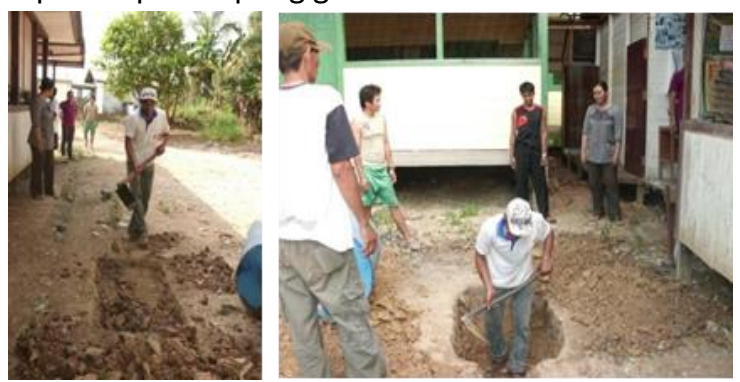
Gambar 11. Proses pemasangan instalasi pipa biogas dan tabung plastik penampung gas

5. Dari tabung plastik penampung gas langsung dihubungkan pada kompor.
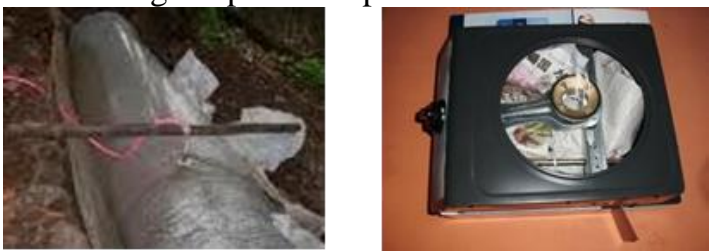

Gambar 12. Tabung plastik penampung gas dan kompor gas

\section{Cara Pengoperasian Reaktor/Digester Biogas}

1. Buat campuran kotoran ternak dan air dengan perbandingan $1: 2$ (bahan biogas)

2. Masukkan bahan biogas ke dalam reaktor melalui tempat pengisian sebanyak 2000 liter atau maksimal $80 \%$ dari volume digester selanjutnya akan berlangsung proses produksi biogas di dalam reaktor.

3. Setelah kurang lebih seminggu reaktor biogas dan penampung biogas akan terlihat mengembung dan mengeras karena adanya biogas yang dihasilkan. Biogas sudah dapat digunakan sebagai bahan bakar, kompor biogas dapat dioperasikan.

4. Sekali-sekali reaktor biogas digoyangkan supaya terjadi penguraian yang sempurna dan gas yang terbentuk di bagian bawah naik ke atas, lakukan juga pada setiap pengisian reaktor.

5. Pengisian bahan biogas selanjutnya dapat dilakukan setiap hari, yaitu sebanyak +40 liter setiap pagi dan sore hari. Sisa pengolahan bahan biogas berupa sludge (lumpur) secara otomatis akan keluar dari reaktor setiap kali dilakukan pengisian bahan biogas. Sisa hasil pengolahan bahan biogas tersebut dapat digunakan langsung sebagai pupuk organik, baik dalam keadaan basah maupun kering. Hasil penelitian menunjukkan bahwa limbah sisa tersebut memiliki kandungan gizi berupa karbohidrat, protein, lemak, kadar air, dan kadar abu (Seran et al., 2020).

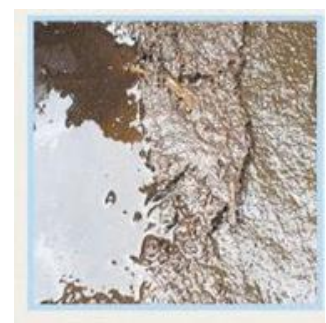

Gambar 13. Sisa pengolahan biogas berupa lumpur Basah yang berguna sebagai kompos

\section{Cara Pengoperasian Kompor Biogas}

1. Buka sedikit kran gas yang ada pada kompor (memutar ke sebelah kiri)
2. Nyalakan korek api dan sulut tepat diatas tungku kompor.

3. Api yang dihasilkan akan berwarna biru, Kompor biogas tidak beda jauh dari kompor elpiji dengan satu pembakar. Kompor dengan satu pembakar rata-rata mengkonsumsi 250-400 liter gas per jam.

4. Apabila menginginkan api yang lebih besar, kran gas dapat dibuka lebih besar lagi, demikian pula sebaliknya. Api dapat disetel sesuai dengan kebutuhan dan keinginan pengguna

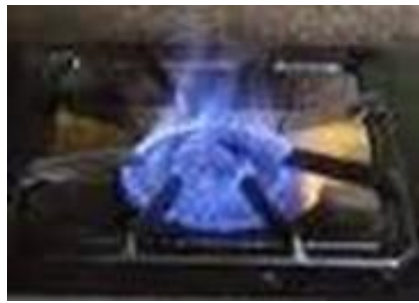

Gambar 14. Api kompor hasil biogas

\section{Pelatihan Pembuatan Batako}

Tidak banyak penduduk lokal yang bergerak di bidang industri rumah tangga, terutama bahan bangunan. Hal ini disebabkan karena penguasaan pengetahuan dan keterampilan yang belum memadai. Batako merupakan bahan bangunan yang umum mereka gunakan untuk pekerjaan konstruksi karena bahan bakunya cukup banyak tersedia, tetapi industri yang memproduksi batako sangat terbatas, hanya ada satu industri yang memiliki mesin press batako/paving block.

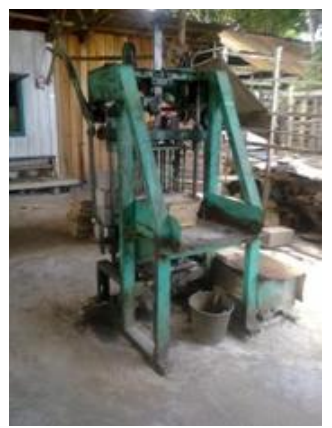

Gambar 15. Mesin cetak batako press industri rumah tangga di Desa Danau Sadar

Harga jual batako di desa Danau Sadar masih cukup mahal, disamping karena harga pasir dan semen yang mahal, penyebab lainnya adalah karena komposisi campuran dan metode pembuatan yang tidak tepat, sehingga batako yang dihasilkan sebagian rusak (Gambar 5.17), dan untuk menutupi kerugian tersebut, maka harga batako yang dijual menjadi lebih mahal. Untuk mengatasi mahalnya harga batako, warga yang memerlukan bahan bangunan tersebut mengantisipasinya dengan membeli cetakan batako manual dan membuat sendiri batako yang mereka perlukan. Hal tersebut kami jumpai di beberapa 
tempat, yang warganya sedang membangun rumah mereka. Dengan pengetahuan seadanya tentang pembuatan batako dan komposisi campuran yang hanya dikira-kira saja, maka hasilnya yang diperoleh pun tidak stabil, kadang kualitasnya baik, kadang juga tidak bisa dipakai, karena batakonya sangat rapuh, prinsipnya bagi mereka yang penting mendapatkan batako yang murah.

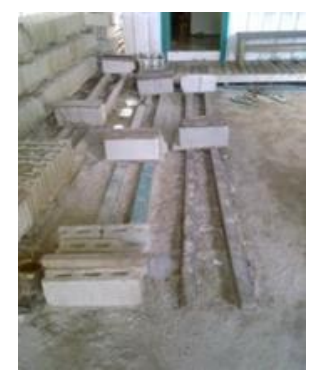

Gambar 16. Hasil produksi batako yang rusak karena campuran yang tidak baik

Hal tersebut disebabkan kurangnya pengetahuan tentang sifat-sifat material pasir, semen dan air, metode untuk mendesain campurannya, proses pencampuran dan pencetakan batako, serta metode perawatannya. Untuk itu, pelatihan pembuatan batako bagi warga perlu dilakukan, baik meraka yang sudah bergerak di industri tersebut, maupun warga yang berminat untuk membuka usaha pembuatan batako ataupun untuk warga yang mau mencetak batako untuk keperluan pribadi.

Tujuan pelatihan pembuatan batako di desa Danau Sadar adalah sebagai berikut:

a. Mengetahui ruang lingkup pekerjaan pembuatan produk beton.

b. Mampu menentukan bahan yang sesuai untuk pembuatan batako.

c. Mampu menentukan mutu bahan yang berkualitas.

d. Mampu mengayak dan membersihkan bahan sebelum digunakan.

e. Mengetahui perbandingan adukan semen dan pasir.

f. Mampu menghitung jumlah bahan yang diperlukan menurut biaya produk.

g. Perawatan batako.

Pelatihan pembuatan batako dimulai dengan penyampaian materi pelatihan berdasarkan modul pelatihan yang telah disusun, kemudian dilanjutkan dengan penyuluhan tinjauan ekonomis dan tanya jawab. Kegiatan pelatihan dilanjutkan persiapan bahan dan peralatan pembuatan batako secara manual dengan praktik pembuatan campuran batako dan pencetakan batako.

Dari hasil wawancara dengan beberapa warga yang mengikuti pelatihan, kebanyakan dari mereka tidak mengetahui bahwa ada faktor-faktor yang mempengaruhi kualitas dari batako. Kualitas batako seperti kekuatan dipengaruhi oleh faktor kualitas bahan pembuat, faktor air semen, komposisi campuran, pemadatan dan perawatan maupun waktu (Darmono, 2006; Sutami, 2014; Suripatty, 2016 dan Irna Hendriyani, Rahmat, 2017). Melalui pelatihan tersebut, mereka mendapatkan pengetahuan serta pemahaman tentang bagaimana memilih pasir, air dan semen yang berkualitas, bagaiamana menentukan campuran batako berdasarkan kualitas yang diperlukan, bagaimana menentukan komposisi campuran yang ekonomis dan bagaimana perawatan batako.

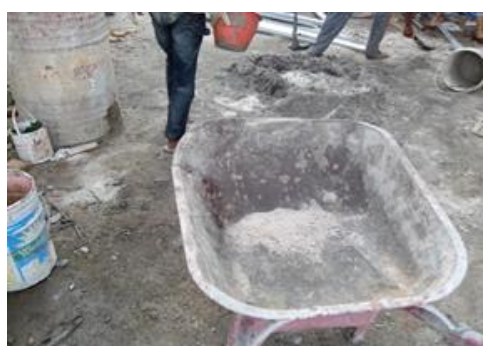

Gambar 17. Campuran batako (pasir, semen dan air)

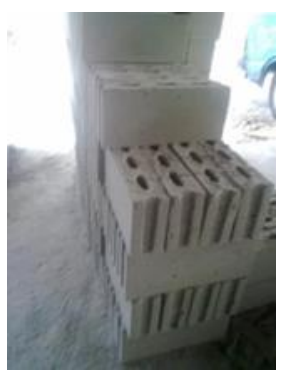

Gambar 18. Hasil produksi batako dengan campuran yang baik

\section{KESIMPULAN}

Adapun kesimpulan yang dapat diambil antara lain:

1. Masyarakat di Desa Danau Sadar menyambut dengan baik kegiatan pengabdian kepada masyarakat yang dilaksanakan oleh Universitas Palangka Raya, ke depan mereka berharap dilakukan kegiatan PKM secara rutin di desa tersebut.

2. Biogas merupakan alternatif pengganti bahan bakar minyak yang ramah lingkungan dan nerupakan solusi baru untuk mengatasi polusi yang ditimbulkan akibat kotoran dari hewan ternak.

3. Untuk kotoran Babi per kg dapat menghasilkan gas sekitar 0,040 - 0,059 m3 sedangkan untuk ayam per kg dapat menghasilkan 0,065-0,116 m3

4. Pembuatan biodigester dapat dilakukan dengan cara yang sederhana dengan memanfaatkan alat yang mudah didapat dan biaya yang relatif murah 
5. Hasil limbah dari biogas dapat dimanfaatkan sebagai pupuk tanaman

6. Sifat-sifat dan kualitas batako ditentukan oleh beberapa faktor, antara lain kualitas bahan pembuat, faktor air semen, komposisi campuran semen dan pasir, pemadatan dan perawatan.

\section{Saran}

1. Masyarakat di Desa Danau Sadar menyambut dengan baik kegiatan pengabdian kepada masyarakat yang dilaksanakan oleh Universitas Palangka Raya, ke depan mereka berharap dilakukan kegiatan PKM secara rutin di desa tersebut.

2. Mengingat banyaknya kegiatan pengabdian yang dapat dilakukan, tim Pengabdi berharap, ke depan dana/pagu untuk kegiatan seperti ini dapat ditingkatkan/diperbesar, sehingga masyarakat yang mendapatkan manfaat kegiatan PKM dapat lebih luas

3. Kapasitas biodigester bisa diperbesar agar produk biogasnya bisa mencukupi kebutuhan untuk memasak dengan kapasitas yang lebih besar lagi.

4. Perlu dilakukan pengecekan terhadap suhu (20-30 $\left.{ }^{\circ} \mathrm{C}\right), \mathrm{pH}(6,6-7)$ dan pengadukan terhadap bahan baku dalam biodigester supaya kadar metana dalam biogas $50-70 \%$.

5. Untuk mempercepat proses pembentukan gas bisa dipakai bahan untuk mempercapat dekompose misalnya EM4 yang bisa diperoleh dengan bebas dipasaran

\section{DAFTAR PUSTAKA}

Darmono (2006) Teknologi Pembuatan Bahan Bangunan Berbahan Pasir hasil erupsi Merapi dilereng bagian utara. Teknik Sipil 1(4): 75-89.

Elly FH, Lomboan A, Kaunang CL, et al. (2020) Teknologi Biogas dengan Bahan Baku Bersumber dari Limbah Sapi. SNITT POLTEKBA 4: 455-459.

Darmono (2006) Teknologi Pembuatan Bahan Bangunan Berbahan Pasir hasil erupsi Merapi dilereng bagian utara. Teknik Sipil 1(4): 75-89.
Elly FH, Lomboan A, Kaunang CL, et al. (2020) Teknologi Biogas dengan Bahan Baku Bersumber dari Limbah Sapi. SNITT POLTEKBA 4: 455-459.

Irna Hendriyani, Rahmat SMD (2017) Research of Manufacture Brickworks With Hvs Waste. SNITT POLTEKBA: 316-321.

Mayang RA, Atiqa OI, Naryono E, et al. (2019) Pengaruh Kotoran Sapi Dan Ukuran Partikel Terhadap Pembentukan Biogas. Distilat: Jurnal Teknologi Separasi 5(2): 41-46. DOI: 10.33795/distilat.v5i2.18.

Putri AAIK, Asmara WS and Aryana K (2014) Pengaruh Jenis Kotoran Ternak terhadap Kuantitas Biogas. Jurnal Kesehatan Lingkungan 4: 45-49.

Putri RE, Andasuryani A and Pratiwi I (2019) Studi Pemanfaatan Kotoran Sapi Sebagai Sumber Biogas di Nagari Aie Tajun Kecamatan Lubuk Alung Kabupaten Padang Pariaman. Jurnal Dampak 16(1): 26-30.

Seran PRC, Ati VM and Kadang L (2020) Analisis Kandungan Gizi Limbah Padat ( sludge ) pada Pembuatan Biogas Kotoran Ternak Sapi Bali ( Bos sondaicus ). Jurnal Biotropikal Sains 17(1): 1-10.

Suriman DKP, Soputan JEM, Kalele JAD, et al. (2021) Kombinasi feses sapi dan babi sebagai sumber biogas. Zootec 41(1): 181. DOI: 10.35792/zot.41.1.2021.32560.

Suripatty HJ (2016) Analisa Kualitas Proses Produksi Analisa Kualitas Proses Produksi Produk Batu Batako PT. Karya Papua Nabire. Jurnal FATEKSA 1(1): 3138.

Sutami JI (2014) Kuat tekan batako dengan variasi bahan tambah serat ijuk 1). (September): 491-497.

Yahya Y, Tamrin T and Triyono S (2018) Produksi Biogas dari Campuran Kotoran Ayam, Kotoran Sapi, dan Rumput Gajah Mini (Pennisetum Purpureum cv. Mott) dengan Sistem Batch. Jurnal Teknik Pertanian Lampung (Journal of Agricultural Engineering) 6(3): 151. DOI: 10.23960/jtep-I.v6i3.151-160. 